\title{
Efektivitas Metode Tabarak di Outdoor dalam Meningkatkan Kemampuan Menghafal Surah Pendek pada Anak Usia Dini
}

\author{
Khotimatus Sa'diyah ${ }^{1}$, Diana ${ }^{2}$, Deni Setiawan ${ }^{3}$ \\ 1,2,3 Program Magister Pendidikan Anak Usia Dini, Universitas Negeri Semarang \\ e-mail : Khatimatussadiyah656@gmail.com¹, Diana@gmail.unnes.ac.id², \\ deni.setiawan@mail.unnes.ac.id
}

\begin{abstract}
ABSTRAK. Tujuan penelitian ini untuk mengetahui peningkatan perkembangan kemampuan menghafal surah pendek pada anak usia dini melalui metode tabarak di outdoor. Metode tabarak merupakan metode yang memudahkan anak usia dini dalam menghafal surah pendek Al-Qur'an. Penelitian ini menggunakan pendekatan kualitatif deskriptif dengan jenis data pengumpulan observasi dan wawancara dan dokumentasi. Teknik analisis data pada peneliitian ini yaitu dengan data mol Miles dan Huberman. Subjek dalam penelitian ini yaitu seorang anak TK B (5-6 tahun), dua guru dan kepala sekolah. Hasil penelitian ini menunjukkan bahwa metode tabarak di outdoor efektif dalam meningkatkan kemampuan menghafal surah pendek pada anak usia dini.
\end{abstract}

Kata Kunci : Metode Tabarak; Kemampuan Menghafal; Anak Usia Dini.

ABSTRACT. The purpose of this study was to determine the development of the ability to memorize short surahs in early childhood through the tabarak method in the outdoor. The tabarak method is a method that makes it easier for young children to memorize short surahs of the Qur'an. This study uses a descriptive qualitative approach with the types of data collection observations and interviews and documentation. The data analysis technique in this research is the Miles and Huberman mole data. The subjects in this study were a kindergarten B child (5-6 years old), two teachers and the principal. The results of this study indicate that the outdoor tabarak method is effective in improving the ability to memorize short surahs in early childhood.

Keyword : Tabarak Method; Memorization Ability; Early Childhood

\section{PENDAHULUAN}

Pendidikan anak usia dini adalah anak yang berusia 0 sampai 8 tahun yang berada pada proses tumbuh dan berkembang secara fisik dan intelektual sehingga mereka sanggup untuk menempuh jenjang pendidikan lebih lanjut. Pendidikan anak usia dini merupakan salah satu bentuk penyelenggaraan pendidikan yang menitik beratkan pada peletakan dasar ke arah pertumbuhan dan enam perkembangan yaitu agama dan moral, fisik motorik, kognitif, bahasa, sosial-emosional, dan seni, sesuai dengan keunikan dan tahap-tahap perkembangan sesuai kelompok usia dini seperti yang tercantum dalam Permendikbud 137 tahun 2014 tentang Standar Nasional PAUD. Undang-Undang No 20 Tahun 2003 memuat tentang Sistem Nasional Pasal 1 ayat 14 
menyatakan bahwa pendidikan anak usia dini (PAUD) adalah suatu upaya pembinaan yang ditunjukkan kepada anak sejak lahir sampai dengan usia enam tahun yang dilakukan melalui pemberian rangsangan pendidikan untuk membantu pertumbuhan dan perkembangan jasmani dan rohani, agar anak memiliki kesiapan dalam memasuki pendidikan lebih lanjut, baik pendidikan secara formal disekolah maupun secara non formal [1]. Proses pembelajaran terhadap anak juga harus memperhatikan karakteristik yang ada dimiliki dalam tahap perkembangan pada anak. Bagi orangtua, anak merupakan harapan di masa mendatang dan setiap orangtua pasti menginginkan anaknya tumbuh sebagai anak yang sehat dan cerdas. Tetapi bukan hanya kecerdasan intelektual saja yang harus diberikan pada anak namun kecerdasan spiritual juga harus ditanamkan dalam diri anak.

Salah satu perkembangan pada pendidikan anak usia dini terutama untuk kecerdasan spiritual adalah mengembangkan nilai-nilai keagamaan dan moral anak. Nilai-nilai agama dan moral sangat penting diperkenalkan dan diterapkan oleh orang tua dan pendidik sejak dini. Orang tua mempunyai peran besar dalam membimbing, merawat, dan membimbing anak, sehingga dengan mengenalkan agama anak dapat menjadi seorang yang berbudi luhur dan bermoral. Anak harus dibekali dengan ilmu agama sejak dini, agar anak kelak dewasa dapat membedakan yang benar dan salah. Pemahaman agama pada anak usia dini dapat diterapkan melalui pendidikan agama baik dilakukan oleh orang tua maupun pendidik. Kegiatan transformasi nilai pendidikan Islam anak masih dilakukan dimasa pandemi covid 19, walaupun tidak semua nilai agama ditanamkan pada anak[2].

Pendidikan agama bertujuan untuk menanamkan keimanan serta ketaqawaan pada anak, sehingga perkembangan anak baik rohani maupun jasmani dapat terwujud. Menanamkan keimanan dan ketaqwaan pada anak dapat diterapkan salah satunya dengan mengenalkan Al-Qur'an pada anak sejak usia dini. Hal ini dikuatkan oleh teori dari Herma et al bahwa untuk mengembangkan potensi anak agar menjadi manusia yang beriman dan bertaqwa kepada Allah SWT yaitu dengan mengenalkan dan mendekatkan anaknya dengan Al-Qur'an, karena Al-Qur'an merupakan sumber utama dalam islam yang mencakup semua aspek kehidupan dan berfungsi sebagai pedoman da petunjuk bagi manusia[3]. Setiap orang yang beragama islam harus dapat menghafal AlQur'an, sekurang-kurangnya dapat menghafal surah pendek yang terdapat pada juz 30 (Juz 'Amma), karena surah-surah tersebut merupakan bacaan yang digunakan dalam sholat. Waktu yang kita miliki sekarang sangat berharga, jangan disia- siakan untuk melakukan sesuatu yang tidak bermanfaat. Untuk memanfaatkan waktu yang ada sebagai pendidik maupun orangtua, kita harus melakukan kegiatan yang dapat mengembangkan kecerdasan anak. Menurut Rodiawati bahwa pendidikan berkenaan dengan keimanan dan ketaatan anak sejak dini mengamati ajaran-ajaran dalam prosedur iman dan taqwa anak adalah (1) mengarahkan anak mengatakan lafaz Allah SWT. ia diajarkan aturan membaca kalimat keyakinan/tauhid. (2) Menumbuhkan mahaba dengan Allah SWT dan rasul-Nya sejak dini kepada anak. (3) Memberikan pengetahuan tentang al-Qur'an kepada anak sejak dini. (4) Mengajar anak dalam melaksanakan shalat. (5) mengajar anak agar berakhlak yang baik[4]. 
Sehubungan dengan pengembangan aspek nilai-nilai dan moral agama, khususnya pada kemampuan menghafal surah pendek dalam Al-Qur'an. Kemampuan menghafal Al-Qur'an merupakan aktivitas yang kaitannya sangat erat dengan memori dalam otak sehingga anak membutuhkan motivasi dari pendidik maupun orangtua, karena sebagian besar anak-anak belum mempunyai tanggung jawab penuh terhadapa hafalannya, mereka juga belum mempunyai strategi sendiri untuk melakukan pengulangan terhadap informasi yang sudah diterimanya dalam hal ini adalah bacaan Al-Qur'an yang sudah dihafalnya [5].

Menghafal pada saat usia dini sangatlah enak karena jika semakin dini hafalannya selesai, maka mereka juga akan punya waktu untuk mempelajari banyak hal lain. Pada saat itu apapun yang mereka pelajari, mereka punya modal dasar berupa hafalan dalam dada mereka [6]. Menghafalkan al-Qur'an merupakan salah satu bentuk interaksi umat Islam dengan al-Qur'an yang telah berlangsung secara turun menurun sejak al-Qur'an pertama kali turun kepada Nabi Muhammad SAW hingga sekarang dan masa yang akan datang Allah SWT telah memudahkan al-Qur'an untuk dihafalkan, baik oleh umat Islam yang berasal dari Arab maupun selain Arab yang tidak mengerti arti kata-kata dalam alQur'an yang menggunakan bahasa Arab [7]. Menghafal merupakan proses mempelajari Al-Qur'an secara keseluruhan mulai dari surah Al-Fatihah hingga surah An-Nas dengan cara menghafalkannya dan selalu ingat saat mengucapkan dengan tanpa melihat mushaf dengan tujuan semata-mata hanyalah mengharap ridho Allah SWT [8]. Guru dalam melaksanakan pembelajaran harus menggunakan strategi yang terdiri dari pemilihan metode yang sesuai dengan tema pembahasan yang diajarkan serta memperhatikan media pembelajaran dalam meningkatkan hasil pembelajaran yang lebih baik. Metode yang cocok untuk memudahkan anak untuk meningkatkan kemampuan menghafal surah pendek adalah metode tabarak.

Metode tabarak merupakan metode yang menggunakan panca indera seperti penglihatan dan pendengaran [9]. Metode ini juga membantu anak usia dini sampai remaja untuk mengingat kemampuan menghafalnya bersifat lama. Adapun pada proses menghafal menggunakan metode Tabarak terdiri dari 7 level. Metode ini terilhami oleh pengalaman Dr.Kamil el-Laboody dalam mengarahkan anaknya yang bernama Tabarak. Awalnya, anak lebih banyak diperdengarkan baik dari ustadzah maupun orang tuanya atau murattal. Satu ayat bisa diulang sampai 3 kali yang diputar sebanyak 20 kali dan anak diminta untuk mendengarkan dengan seksama dan melihat bagaimana ustadzah atau orangtua mengucapkan tiap kata. Dalam menghafal metode tabarak ini, awalnya Dr. Kamil el-Laboody menerapkan metode ini kepada ketiga anaknya yaitu (Tabarak, Yazid dan Zeenah) yang pada saat itu, belum bisa menghafal al-Qur'an dengan cara membacanya. Bacaan al-Qur'an hanya diperdengarkan sembari mulai diperkenalkan pula pada huruf dan harakat al-Qur'an. Yang dimulai dari surah-surah pendek atau juz 30. Saat di rumah beliau menalqinkan surah-surah kepada Tabarak, setelah anak diminta untuk menghafalkan surah yang telah dihafalnya. Apabila Tabarak berhasil menghafal surahnya, maka orangtuanya akan memberikannya hadiah yang disukai oleh Tabarak. Selain itu terdapat makanan khusus berupa susu, madu, dan kurma untuk 
menjaga stamina. Seperti itulah cara Dr. Kamil el-Laboody beserta istrinya dalam mengajarkan menghafal al-Qur'an kepada anaknya [6].

Berdasarkan hasil observasi yang peneliti lakukan di TK Tahfidzul Qur'an Permata Bunda Semarang dalam metode tabarak masih di laksanakan dalam ruangan, sehingga anak cepat bosan dan tidak mau menambah hafalan surah pendek. Terdapat cara untuk menghindari anak bosan dalam menghafal surah pendek dalam Al-Qur'an maka diperlukan suasana yang menyenangkan yaitu dengan melakukan metode tabarak di luar ruangan (outdoor). Anak-anak juga akan lebih mudah mengingat dengan baik ayat demi ayat melalui kegiatan dengan metode tabarak di outdoor sehingga kemampuan menghafal surah pendek dapat meningkat secara maksimal. Selain itu, kegiatan menghafal surah pendek dengan metode tabarak di outdoor diharapkan untuk diimplementasikan pendidik maupun orangtua, sehingga anak akan termotivasi dalam menghafal.

Metode tabarak ini mendominasi semua metode menghafal Al-Qur'an karena metode tabarak cara mengajarnya dan belajarnya dilakukan dengan santai tanpa adanya suatu paksaan dan proses pembelajarannya audiovisual [3]. Proses pembelajaran audiovisual yaitu anak diputarkan murottal dari syekh-syekh terkenal menggunakan alat pendukung seperti speaker dan laptop, sehingga anak dapat berkonsentrasi dalam menghafal. Selain pembelajaran audiovisual, pembelajaran di outdoor merupakan pembelajaran yang dilakukan di luar ruangan dengan suasana yang menyenangkan, sehingga anak tidak akan cepat bosan dalam menghafal. Setelah anak melakukan kegiatan menghafal srah pendek, anak diminta untuk istirahat sambil muraj'ah hafalan kemarin dan guru menyediakan makanan Tabarak yaitu susu dan kurma yang diberikan pada anak dengan cara antri. Setelah itu, anak kemudian diputarkan kembali surah yang sudah di hafalkan tadi sampai anak mengingatnya. Sehingga metode yang dikembangkan untuk meningkatkan kemampuan menghafal surah pendek dalam AlQur'an adalah metode tabarak yang di outdoor.

Menurut penelitian yang dilakukan oleh Raudatul Jannah (2017) terkait dengan metode tabarak menyimpulkan bahwa program tahfidz untuk anak dengan metode tabarak ini efektif. Sedangkan penelitian oleh Andarini (2018) menunjukkan bahwa pemberian perlakuan mengahafal Al-Qur'an metode tabarak efektif untuk meningkatkan memori menghafal pada anak usia dini. Dan penelitian ini diperkuat dengan penelitian oleh Adik (2021) menunjukkan bahwa penggunaan metode tabarak dalam menghafal Al-Qur'an bukanlah satu-satunya metode yang bisa digunakan untuk menghafal anakanak usia dini, tapi metode ini bisa menjadi alternatif bagi para orangtua yang menginginkan anaknya menjadi penghafal Al-Qur'an tapi bingung karena belum bisa membaca Al-Qur'an. Berdasarkan hasil studi pendahuluan dan penelitian terdahulu maka peneliti tertarik untuk melakukan penelitian tentang efektivitas metode tabarak di outdoor dalam meningkatkan kemampuan menghafal surah pendek

\section{METODE}

Penelitian ini menggunakan metode kualitatif dengan jenis deskriptif yang berfokus pada kejadian lapangan dengan cara menggambarkan dan menjelaskan objek yang sesuai dengan fakta yang terjadi dilapangan. Subjek dalam penelitian ini sebanyak 
4 orang yakni seorang anak TK B usia 5-6 tahun, seorang kepala sekolah, 2 orang guru yang mengajar di TK B. Lokasi penelitian dilakukan pada TK Tahfidzul Qur'an Permata Bunda, Gunungpati Semarang. Data ini dikumpulkan menggunakan teknik observasi dan wawancara terstruktur dan dokumentasi. imana peneliti melakukan proses pengamatan di lapangan dengan mengumpulkan informasi yang diperlukan. Selain itu juga menggunakan wawancara terstruktur, peneliti membuat daftar pertanyaan yang akan diajukan kepada reponden lengkap dengan jabawabannya. Selain itu peneliti juga menggunakan dokumentasi guna mengumpulkan data baik dari buku, dokumen, dan pengamatan lapangan. Data yang sudah tersedia kemudian dianalisis menggunakan analisis deskriptif kualitatif. Data dianalisis menggunakan tiga tahap dalam model Miles dan Huberman yakni: reduksi data (mengumpulkan data dan informasi penting dari hasil observasi, wawancara, dan dokumentasi); penyajian data (rangkuman deskriptif dari hasil yang diperoleh untuk memudahkan rencana kerja selanjutnya); dan penarikan kesimpulan (menguji kesimpulan dengan membandingkan teori yang relevan, mengecek ulang hasil penelitian, serta membuat kesimpulan berupa temuan baru) [12].

\section{HASIL DAN PEMBAHASAN}

Dari hasil penelitian yang dilakukan peneliti mengenai efektivitas metode tabarak di outdoor dalam meningkatkan kemampuan menghafal surah pendek pada anak usia dini, peneliti menemukan fakta bahwa metode tabarak tersebut sudah berlangsung selama dua tahun. Adapun proses dari pelaksaan metode tabarak ini dilakukan dengan cara kegiatan pembiasaan sehari-hari sebelum kegiatan pembelajaran dimulai. Sebagaimana hasil wawancara dengan Ibu Sholiah, selaku guru 1 di TK B :

"Proses pelaksanaannya itu kita disini mulai setengah delapan anak langsung masuk dan antri di depan guru untuk melakukan hafalan surah pendek misal surah Ad-Dhuha. Sebelum anak melakukan hafalan guru terlebih dahulu mentalqin anak, yaitu dengan satu ayat bisa diulang tiga kali sampai duapuluh kali dan anak diminta untuk memperhatikan bagaimana guru mengucapkan tiap ayat, setiap satu hari anak itu menghafal lima ayat. Pada anak TK B yang berusia 5-6 tahun menggunakan metode tabarak yang level 1 yaitu menghafal juz 30 dan pengenalan huruf-hiruf hijaiyah dengan harakat. Dari jam setengah delapan sampai sembilan setiap anak ditalqin terlebih dahulu lalu kemudian anak menghafalkan dan setiap harinya anak melakukan muroja'ah (pengulangan) hafalan kemarin dengan diputarkan murottal dari syekh melalui speaker maupun leptop, misal hari kemarin anak telah menghafal surah Ad-Dhuha ayat 1-5 di hari selanjutnya kita masuk surah Ad-Dhuha dari ayat 6-10, maka sebelum masuk surah Ad-Dhuha ayat 5-6, anak melakukan muraja'ah surah Ad-Dhuha ayat 1-5 terlebih dahulu. Dan pada waktu istirahat guru juga memutarkan murottal full surah Ad-Dhuha, agar anak familiar dengan bacaan surah Ad-Dhuha".

Dalam proses meningkatkan kemampuan menghafal surah pendek di outdoor ini tidak ada perbedaan bagi setiap anak, baik yang memiliki gaya belajar audio, visual maupun kinestetik. Sebagaimana hasil wawancara dengan Ibu Diyah, selaku kepala sekolah TK Tahfidzul Qur'an Permata Bunda: “Semua anak wajib melakukan kegiatan 
pembiasaan sehari-hari yaitu menghafal surah pendek dengan metode tabarak yang bertujuan untuk meningkatkan kemampuan menghafal surah pendek pada anak. Disini kami masih fokus dengan metode tabarak dengan pembelajaran audio visual, tidak dibedakan gaya belajar setiap anak, jadi gurunya membimbing pada saat belajar, menghafal dan mendengarkan. Apabila anak bosan menghafal surah pendek, biasanya anak-anak setiap sebulan sekali sekolah mengadakan orogram menghafal di luar ruangan (outdoor) sambil mencari suasana menyenangkan, agar anak tidak merasa ada paksaan dalam menghafal surat pendek, sehingga anak dapat meningkatkan kemampuan menghafal surah pendek secara maksimal".

Jadi dalam metode tabarak di outdoor dalam meningkatkan kemampuan menghafal surah pendek pada anak usia dini guru sangat berperan penting dalam proses pelaksanaanya, guru sangat memperhatikan peserta didik, agar anak dalam menghafal surah pendek senang tanpa ada tekanan dan paksaan. Sebagaimana hasil wawancara dengan Ibu Ima, selaku guru 2 yang mengajar di TK B: "Kalau sudah kita arahkan diawal, level 1 ini kan ibarat kata pondasi yang pertama, jadi sistem yang memang kita ajarkan itu memang di level 1, sehingga di level selanjut-selanjutnya sudah terbawa bagaimana seharusnya sikap dia dilokal. Di sekolah ini menerapkan metode tabarak di outdoor bertujuan agar anak itu tidak merasa cepat bosan dalam menghafal surah pendek. Namun dengan diterapkannya metode tersebut di outdoor kami dari pihak sekolah tetap masih menerapkan aturan-aturan di dalam seperti apa, sehingga mau anak yang super aktif atau pasif itu anaknya sudah mengkondisikan diri dia untuk mengikuti proses hafalannya dengan patuh, sehingga menyikapi hal ini tidak adak masalah untuk bagaimana karakter anak seperti apa. Disini anak harus tetap fokus dalam meningkatkan kemampuan menghafal surah pendek meskipun dilaksanakan outdoor, tidak ada yang main-main sendiri, sibuk sendiri dan tidak mengganggu anak lain". Dan untuk penggunaan metode tabarak di outdoor sangat efektif dalam meningkatkan kemampuan menghafal surah pendek pada anak usia dini".

Berdasarkan hasil wawancara tersebut, jelas bahwa guru dalam menerapkan metode tabarak di outdoor dalam meningkatkan kemampuan menghafal surah pendek pada anak usia dini sudah benar-benar memahami metode tersebut dan juga mengikuti pelatihan langsung metode tabarak. Sebagaimana hasil wawancara dengan Ibu Sholiah, selaku guru 1 di TK B: "Sesuai dengan programnya yang di TK Tahfidzul Qur'an Permata Bunda itu ada yang namanya Tahfidz Outdoor atau menghafal di luar ruangan. Mereka anak-anak menghafal surat pendek di luar ruangan. Jadi setiap sebulan sekali, kami mengadakan tahfidz outdoor yaitu menghafal di luar ruangan yang biasanya mereka menghafal di dalam kelas masing-masing. Program ini diadakan agar mereka lebih semangat dan senang untuk meningkatkan kemampuan menghafal surah pendek, mengenalkan bahwa menghafal itu tidak hanya di dalam ruangan atau kelas, tetapi bisa di luar ruangan. Jadi ketika mereka di luarpun mereka lebih baik untuk menghafal surat pendek".

Hasil wawancara tersebut bahwa guru juga memberikan program yang sangat menarik bagi anak, yaitu tahfidz outdoor. Program tersebut bertujuan agar anak-anak lebih semangat, tidak cepat bosan dan senang dalam meningkatkan kemampuan 
menghafal surah pendek yang di luar ruangan (outdoor). Anak-anak juga merasa senang ketika menghafal di outdoor. Sebagaimana hasil wawancara dengan seorang anak TK B (usia 5-6 tahun): "Aku senang menghafal surah pendek saat berada di luar ruangan, senang karena di luar juga bisa menghafal sambil bermain juga. Terus hafalanku juga jadi cepet masuk ke kepala".

Selain itu, metode tabarak di outdoor ini menggunakan silabus buku panduan dari Syekh Kameel, dan kurikulum yang sudah ditentukan level 1 sampai dengan level tujuh. Untuk ayat yang didengarkan, dihafalkan, dan di muroja'ahkan sudah sesuai standar. Secara teori untuk indikator keberhasilan tidak ada indikator khusus dalam penilaian, indikator yang digunakan berdasarkan ketentuan dari sekolah yaitu untuk satu surah, biasanya anak menghafalkan selama dua minggu yang kemudian untuk mengetes keberhasilan anak dalam hafalnya. Guru melakukan evaluasi atau tes ujian hafalan setiap akhir semester, untuk target satu semester anak harus menghafal 10 surah pendek.

Hasil penelitian diatas menunjukkan bahwa penerapan metode tabarak di outdoor efektif dalam meningkatkan kemampuan menghafal surah pendek pada anak TK B usia 5-6 tahun di TK Tahfidzul Qur'an Permata Bunda. Program menghafal surah pendek pada anak usia dini di TK Tahfidzul Qur'an Permata Bunda dilaksanakan dengan menggunakan metode tabarak. Adapun program Tahfidz Outdoor yaitu program menghafal surah pendek di outdoor dengan metode tabarak yang dilaksanakan dalam sebulan sekali dengan berbantuan media audio seperti speaker. Metode tabarak di outdoor dalam menghafal surah pendek dilakukan sambil bermain. Pelaksanannya yaitu anak berbaris, berdoa bersama, melakukan senam ringan, kemudian diputarkan rekaman murattal juz'amma yang dibacakan oleh para Syekh atau Qori, anak menyaksikan, mendengarkan dan megikuti rekamana tersebut bersama-sama yang diikuti oleh gurunya, bacaan murattalnya diulang perayat sebanyak 3 kali dan diputarkan sebanyak 20 kali agar mudah tersimpan dalam memori anak dan berlanjut seterusnya sesuai dengan target yang dihafalkan pada setiap pertemuan mengikut pada timelite atau sejenis RPPH.

Menghafal metode tabarak dimulai dari surah Al-Fatihah kemudian lanjut ke AnNaba sampai An-Nas. Apabila ada anak yang cara mengikutiya lantang (keras) maka anak tersebut mendapatkan bintang dari gurunya begitupun seterusnya. Kemudian, guru memberhentikan audio murattal tersebut, guru memutar surah melalui MP3 dan anak diminta untuk mengikuti/ murajaah hafalan yang telah dihafal pada pertemuan yang lalu yakni dari surah An-Naba-Al-Fajr. Setelah itu, anak diminta untuk mengantri sambil murajaahkan hafalannya pada pertemuan yang kemarin. Setelah murajaahkan hafalannya satu persatu, anak pun diminta untuk mengambil susu dan kurma yang telah disediakan dan menikmati tanpa berbicara apabila ada yang berbicara diberikan SP1 apabila anak masih mengulang maka makanannya diambil oleh gurunya. Cara menghafal anak berbeda sesuai dengan daya ingatan anak, pelafalan serta umurnya.

Pembelajaran menghafal surah pendek dengan metode tabarak di outdoor sangat efektif dalam memfokuskan anak dalam meningkatkan kemampuan menghafal surat pendek pada anak usia dini. Tujuan menggunakan metode tersebut secara outdoor agar 
anak tidak bosan dengan hanya belajar didalam kelas, lebih rileks sekaligus memberikan nuansa tafakur alam. Hal yang perlu diingat oleh para pendidik PAUD dalam menerapkan pembelajaran menghafal surah pendek dalam Al-Qur'an adalah karakteristik anak usia dini. Pendidik tidak boleh memaksakan hafalan yang terlalu berat yang tidak sanggup dilakukan oleh anak. Target menghafal surah pendek dalam Al-Qur"an bagi anak usia dini dibatasi hanya pada juz ke 30 dalam satu tahun pelajaran atau dua tahun pelajaran, itupun dilakukan dengan pembimbingan yang intensif di sekolah maupun di rumah dengan bimbingan orang tua, sehingga anak-anak tidak terasa berat untuk menghafal [5].

Aktivitas menghafal surah pendek dalam Al-Qur'an bagi anak usia dini dapat dipengaruhi oleh beberapa faktor. Menurut Sugianto, mencatat beberapa faktor yang dapat menentukkan keberhasilan seseorang dalam menghafal Al-Qur'an diantaranya adalah faktor latihan, motivasi, pribadi, keadaan keluarga, guru dan cara mengajukan, lingkungan dan kesempatan yang tersedia dan faktor motivasi social [12]. Berdasarkan hasil observasi di TK Tahfidzul Qur'an Permata Bunda faktor penghambat penerapan metode tabarak di outdoor dalam meningkatkan kemampuan menghafal surah pendek dalam Al-Qur'an kehadiran anak yang terlambat ke sekolah atau tidak hadir ke sekolah, kurang fokusnya anak saat mendengarkan murrotall ataupun guru saat membacakan surah pendek dan batas waktu pembelajaran saat melakukan di outdoor belum berjalan dengan maksimal. Semua faktor ini akan efektif apabila guru yang mengajar lebih bijaksana dan tegas lagi dalam menghadapi anak serta adanya kerjasama antara guru, anak dan orang tuanya. Apabila semuanya dijalankan dengan baik maka proses pembelajarannya akan berjalan dengan baik dan efektif meskipun anak jarang masuk sekolah tetap di rumah tetap diadakan muroja'ah kepada anak.

Hal ini dikuatkan dengan teori dari Qomariah, $\mathrm{N}$ dan Irsyad mengenai faktor penghambat dalam mendidik anak menghafal al-Qur'an yaitu: 1) anak usia dini masih ingin bermain karena menyenangkan bagi anak, 2) anak sakit merupakan kondisi yang dapat menghambat dalam proses menghafal al-Qur'an yang akan terhenti sementara waktu, sehingga hafalan anak tidak bertambah, 3) kesibukan orangtua dapat mengurangi waktu dalam membimbing anak menghafalkan al-Qur'an, serta 4) Dr. kamil telah mengatakan bahwasanya, jika ingin mencapai hasil maksimal dari metode Tabarak ini, semua SOP Tabarak harus diterapkan metode Tabarak wajib diterapkan [13]. Penelitian ini juga dikuatkan dari Firdausi Nuzula, Salsabila, dan Maskuri menunjukkan bahwa metode tabarak dikatakan efektif karena ditemukannya lebih banyak siswa yang dapat menghafal surat An-Naba secara utuh dalam setiap proses pembelajaran yang ada, dalam proses pembelajaran yang ada, dalam proses pembelajaran ini sangat terlihat memberdayakan kemampuan siswa dalam menghafal surat An-Naba pasa anak usia 3 tahun [14].

Keberhasilan dalam meningkatkan kemampuan menghafal surat pendek pada anak usia dini dengan metode tabarak di outdoor dibutuhkan kerjasama antara pendidik dan orangtua, agar dalam pembelajaran menghafal dengan metode ini dapat berjalan dengan maksimal. Perlunya kerjasama dengan pihak orang tua dengan melakukan komunikasi efektif berkaitan dengan kegiatan pembelajaran yang dilakaukan selama 
pembelajaran dari rumah karena pelaksana kegiatan adalah orang tua. Berikan penjelasan mengenai pentingnya memberikan stimulasi sejak dini dan melakukan laporan kegiatan anak kepada guru melalui artikel-artikel ataupun melalui komunikasi langsung[16]. Pada pelaksanaan metode ini, orangtua harus mempunyai komitmen untuk mendatangkan anak di waktu yang tepat serta rajin menghafal, mengontrol hafalan anak, serta rajin memuraja'ahkan anak ketika di rumah, orangtua juga harus melakukan pemantauan kepada anak dan juga kartu mutab'ah anak setiap harinya. Orangtua juga memiliki kewajiban mengantar jemput anak ke sekolah tepat waktu dan membatasi anak dalam menonton TV atau bermain gadget. Kerjasama harus terjalin antara kedua orangtua dan pihak sekolah demi mensukseskan seluruh jenjang yang akan dilalui anak.

\section{KESIMPULAN}

Berdasarkan hasil penelitian dan pembahasan mengenai efektivitas metode tabarak di outdoor menunjukkan bahwa metode tersebut efektif dalam meningkatkan kemampuan menghafal surah pendek pada anak usia dini. Metode tabarak di outdoor merupakan metode yang baik dan efektif bagi anak-anak di TK Tahfidzul Qur'an Permata Bunda. Metode tersebut dilakukan di outdoor yang bertujuan agar anak semangat dan tidak cepat bosan dalam meningkatkan kemampuan menghafal surah pendek. Efektivitas metode tabarak di outdoor ini ditunjukkan dengan adanya faktor keberhasilan dan faktor penghambat. Pada faktor keberhasilan yang paling dominan adalah adanya media alat pendukung yang terdiri dari speaker, laptop, dan alat permainan anak. Sedangkan faktor penghambatnya adalah kehadiran anak yang terlambat ke sekolah atau tidak hadir ke sekolah, kurang fokusnya anak saat mendengarkan murrotall ataupun guru saat membacakan surah pendek dan batas waktu pembelajaran saat melakukan di outdoor belum berjalan dengan maksimal. Selain itu kerjasama antara pendidik dan orangtua merupakan salah satu faktor keberhasilan anak dalam menghafal surah pendek.

\section{PENGHARGAAN}

Terima kasih penulis ucapkan kepada kepala sekolah dan para guru yang di TK Tahfidzul Qur'an Permata Bunda yang telah meluangkan waktunya untuk mengisi instrument penelitian ini dan semua pihak yang telah membantu pelaksanaan penelitian dan penulisan artikel ini. Tidak lupa ucapan terima kasih kepada editor dan reviewer Jurnal Murhum yang sudah memberikan kesempatan sehingga jurnal bisa untuk diterbitkan

\section{REFERENSI}

[1] T. Ariyanti, "Pentingnya Pendidikan Anak Usia Dini Bagi Tumbuh Kembang Anak," J. Din. Pendidik. Dasar, vol. 80, no. 1, pp. 50-58, 2016.

[2] A. T. Andreas Putra, Sufiani, and Jahada, "Transformasi Nilai Pendidikan Islam Anak di PAUD Sultan Qaimuddin Kendari Pada Masa Pandemic Covid 19," Murhum J. Pendidik. Anak Usia Dini, vol. 1, no. 1, pp. 79-90, Jul. 2020, doi: 
10.37985/murhum.v1i1.8.

[3] T. Herma, U. Kusyairy, and M. R. T, "Analisis Penerapan Metode Tabarak Menghafal Al-Qur'an Juz 30 Di Sekolah Tahfidz Al-Husna Balita Dan Anak Makassar," NANAEKE Indones. J. Early Child. Educ., vol. 3, no. 1, p. 37, 2020, doi: 10.24252/nananeke.v3i1.14332.

[4] L. O. Anhusadar and H. Wulandari, "Pengembangan Model Pembelajaran Seni Berbasis Agama Pada Anak Usia Dini," Al-Athfaal J. Ilm. Pendidik. Anak Usia Dini, vol. 2, no. 1, pp. 58-68, Sep. 2019, doi: 10.24042/ajipaud.v2i1.4622.

[5] C. Susianti, "Efektivitas Metode Talaqqi Dalam Meningkatkan Kemampuan Menghafal Al-Qur'an Anak Usia Dini," Tunas Siliwangi Hal., vol. 2, no. 1, pp. 1-19, 2016.

[6] R. F. \& H. I. Masyhud, "Rahasia Suskes 3 Hafidz Qur'an Cilik Mengguncang Dunia,” Jakarta: Zikrul, 2016.

[7] A. Hidayah, "Metode Tahfidz Al-Qur'an Untuk Anak Usia Dini (Kajian Atas Buku Rahasia Sukses 3 Hafizh Quran Cilik Mengguncang Dunia)," J. Stud. Ilmu-ilmu AlQur'an dan Hadis, vol. 18, no. 1, p. 51, 2018, doi: 10.14421/qh.2017.1801-04.

[8] M. Irsyad and N. Qomariah, "Strategi menghafal Al-Quran sejak usia dini," Proc. 2nd Annu. Conf. Islam. Early Child. Educ., pp. 135-148, 2017.

[9] R. Jannah, "Efektivitas Metode Tabarak Dalam Menghafal Al-Qur'an Di Tinjau Dari Gaya Belajar Di SDIT Yayasan Huda Wan Nur," J. Ilmu Pendidik., vol. 4 (2), pp. 552563, 2017.

[10] N. H. Andarini, "Pengaruh menghafal al-Qur'an metode tabarak terhadap peningkatan memori menghafal al-Qur'an pada anak usia dini," vol. 151, no. 2, pp. 10-17, 2018.

[11] R. O. Adik, "Praktik Hafalan Al-Qur'an Pada Anak Usia Dini Dengan Metode Tabarak Di Rutaba Mahya, Cilandak RUTABA MAHYA, CILANDAK," 2021.

[12] Sugiyono, Metode Penelitian Pendidikan: Pendidikan Kuantitatif, Kualitataif dan $R \& D$. Bandung: Alfabeta, 2016.

[13] I. . Sugianto, Kiat Praktis Menghafal Al-Qur'an. Bandung: Mujahid Press, 2006.

[14] M. Qomariah, N dan Irsyad, Metode Cepat dan Mudah Agar Anak Hafal Al-Qur'an. Yogjakarta: Semesta Hikmah, 2016.

[15] S. K. Firdausi Nuzula, Salsabila, Maskuri, "Efektivitas Metode Tabarak Dalam Menghafal Surat An-Naba Anak Usia 3 Tahun Di Rumah Tahfidz Balita Dan Anak Kota Malang," Pendidik. Islam, vol. 5, no. 2, pp. 17-23, 2020.

[16] K. Maryani, "Penilaian dan Pelaporan Perkembangan Anak Saat Pembelajaran di Rumah di Masa Pendemi Covid-19," Murhum J. Pendidik. Anak Usia Dini, vol. 1, no. 1, pp. 41-52, 2020, doi: 10.37985/murhum.v1i1.4. 